\title{
Does Public Service Motivation Matter to Employees' Performance and Or- ganizational Commitment in Sub-district Offices?
}

\author{
Arif Budy Pratama \\ Universitas Tidar \\ arifpratama@untidar.ac.id \\ Aidah Nur Hidayah \\ Universitas Tidar \\ aidahoffa@untidar.ac.id
}

\begin{abstract}
Many studies on Public Service Motivation (PSM) were conducted extensively in the developed countries, including US and Western Europe. In addition, some research on PSM has been conducted in Eastern Asia, all which affirm the positive role that plays in shaping the public sector. That said, studies on PSM in developing countries, including Indonesia is still limited. This is despite the fact that previous research associate PSM with improving public sector performance. The objective of this study is to investigate the relationship between public service motivation, organizational commitment, and individual performance in Magelang Municipality, which is one of the high performing local governments in Indonesia. The data was drawn from 70 government employees in 3 Magelang Municipality sub-district Offices. Meanwhile, to test the research hypothesis, Structural Equation Modelling (SEM) was used. Results of the study validated the previous research findings that indicate positive influence of PSM on organizational commitment and individual performance. The result of this study has a practical implication for human resource development policy in Indonesian public sector. To that end, Public managers should take into account PSM in their managerial practices as it influences employee performance.
\end{abstract}

Keywords: individual performance, organizational commitment, public service motivation, structural equation modelling 


\section{INTRODUCTION}

"All Quiet on the non-Western Front?" is a title that Van der Wal (2015) gives to his systematic literature review article that highlights lack of studies on Public Service Motivation (PSM) in non-western context. Based on his findings, current PSM studies by and large, was based on developed countries context, which are characterized by well developed public administration and public service ethos. To that end, research findings on PSM in the realm of public administration and public service in other geographic regions with different socio-cultural, governance and institutional setting from those in the developed world, may not corroborate those in previous empirical research.

Bangcheng (2009) and Liu \& Tang (2011) in their studies on Eastern Asia, also note the relative lack of PSM research in developing countries and traditional societies. A systematic literature review conducted by Ritz, Brewer, \& Neumann (2016) showed that the US and Western Europe setting has dominated PSM scholarship over the last two decades. This phenomenon makes sense since western public service ethics constitutes the the origin of PSM concept (Perry, 1996), with international comparative studies by and large, juxtapose empirical evidences from the US and Western Europe PSM (Kim et al., 2013). To that end, partial PSM perspectives in the global research community may lead to bias in the generability of PSM concept in public administration scholarship.

To reduce or better still ameliorate such concerns, PSM research should be conducted in developing country setting. In that backdrop, this article tries to empirically test PSM concept in relation to organizational commitment and individual performance in public administration setting in Indonesia. By doing so, this study focusing on PSM in Indonesian civil service, will in some way continue to bridging the existing research gap in the coverage of PSM studies. In this study, we adopt the definition of PSM by Vandenabeele (2007) which is refinement from the original concept by Perry \& Wise (1990). Thus, this study defines PSM as "the beliefs, values, and attitudes that go beyond self-interest and organizational interest, that concern the interest of a larger political entity and that motivate individuals to act accordingly whenever appropriate" (Vandenabeele, 2007).

A number of studies discuss PSM in relation to public bureaucracy within the context of public-sector reform in general and the efforts to enhance public sector performance through human resource management reform. Indonesia, like many other developing countries, has also been involved in various bureaucracy reform efforts that are aimed at improving performance. Some authors use the term 'administrative reform' to highlight the reform in the administrative system as a whole (Daisuke \& Kumorotomo, 1998). This initiative begun with the political reform in 1999's as a response to of the financial crisis which raged and ravaged through South East Asian countries, which triggered along the way, political changes such as the ouster of new order regime in Indonesia (Pratama, 2017b). Since then, civil service reform has become a key priority that is stipulated in the national medium and long term development plans. Government bureaucracy must be effective, efficient and achieve high performance to support government development agenda. To achieve that, modernizing performance management system in the bureaucracy is imperative (Pratama, 2017a). One manifestation of that has been the integration of policies and regulations on bureaucracy reform into performance-based initiatives, which has catapulted the notion of performance into day to day practice in Indonesian public administration.

In the aftermath of with the implementation of decentralization policy in Indonesia, authority to deliver most of the key functions is today under the purview of local governments. The main goal of the policy is to transfer service delivery in the hands of those with better knowledge about needs of service users, which in the end is expected to improve the match between services provided with public needs, as well as service quality (Liando, 2012; Nurtanzila \& Kumorotomo, 2015). Civil records administration constitutes one of the most fundamental services. It includes services that encompass processing and issuing national citizenship 


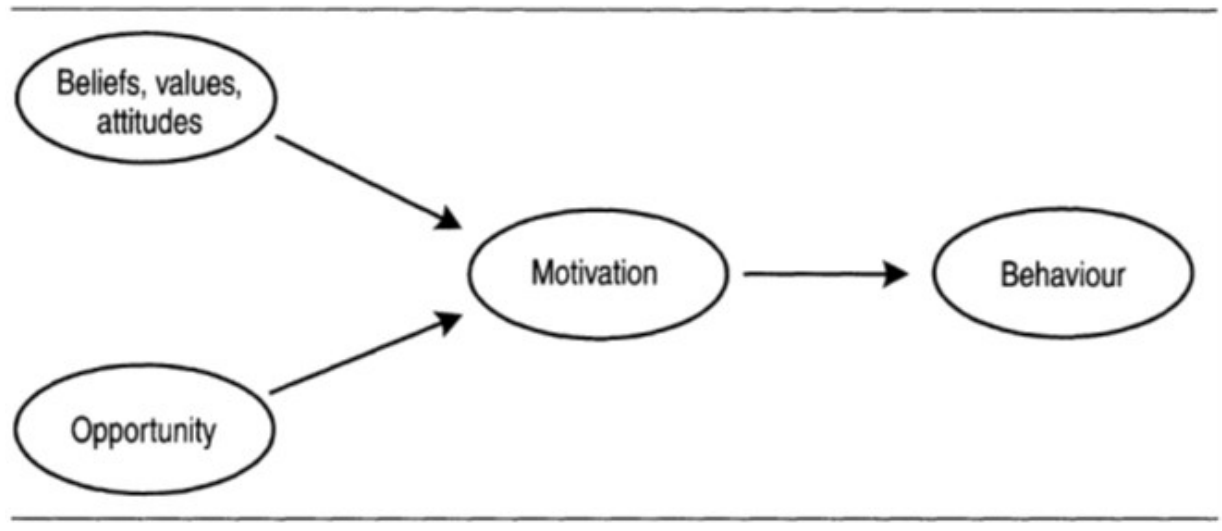

Figure 1. Motivation as an Interactive Concept

Source: Vandenabeele et al., 2006

identification cards, children identification cards, family identification cards, and other related services. The focus of the study was on civil administration services under the jurisdiction of sub district offices which is the government tier that is charged with handling such services. The choice of Magelang Municipality as the focus research area was based on the consideration that it is ranked number one on regional competitiveness index in this respect (central java province) (DPMPTSP Kota Magelang, 2016). In addition, this city has also received several awards in the realm of governance including Innovative Government Award (IGA) 2017 by the Ministry of Home Affairs; and the public information governance award 2017 by the Ministry of Information and Communication. The above awards in governance and transparency are a reflection of the recognition of the achievements that Magelang municipality has made in delivering public services.

The rest of our paper is presented as follows: the first section explains the meaning of PSM and how it differs from work motivation. This is followed by the discussion of the theories and conceptual framework that culminates into research hypotheses. The following section presents analysis results and discussion, which leads to conclusions and implications for public sector managers.

\section{Theoretical Basis and Research Model}

The basic definition of motivation is the drive that induces an individual to do something. It is the motive of an individual toward human action. The theory of motivation as expounded by Vandenabeele, Scheepers, \& Hondeghem (2006) opines that motivation only exists when there is an interaction between individual values and an actual situation that enables a person to realize such values (targeted behavior). Therefore, motivated action is in fact an intermediate variable between the interaction of individual values and behavior. Based on such argument, Vandenabeele et al.(2006) developed an interactive framework of motivation, which highlights the interactive process that underpins individual motivation. The interactive motivation includes beliefs, values, attitude, a combination that translate into behavior. Based on the above logic, behavior is driven by an interactive process, as depicted in Figure 1.

The theoretical framework lay the foundation for the conceptual framework that underlies the research model hence served as guidance on research hypotheses on the relationship between PSM, organizational commitment, and individual performance (Figure 2).

\section{The relationship between PSM and Performance}

Quite a number of previous studies on PSM confirm the existence of a positive relationship between PSM and performance in the public sector (Belle, 2013; Bright, 2007; Leisink \& Steijn, 2009). Belle (2013), specifically examined the role of motivation in the public sector on performance by using an experiment in an Italian public hospital. 


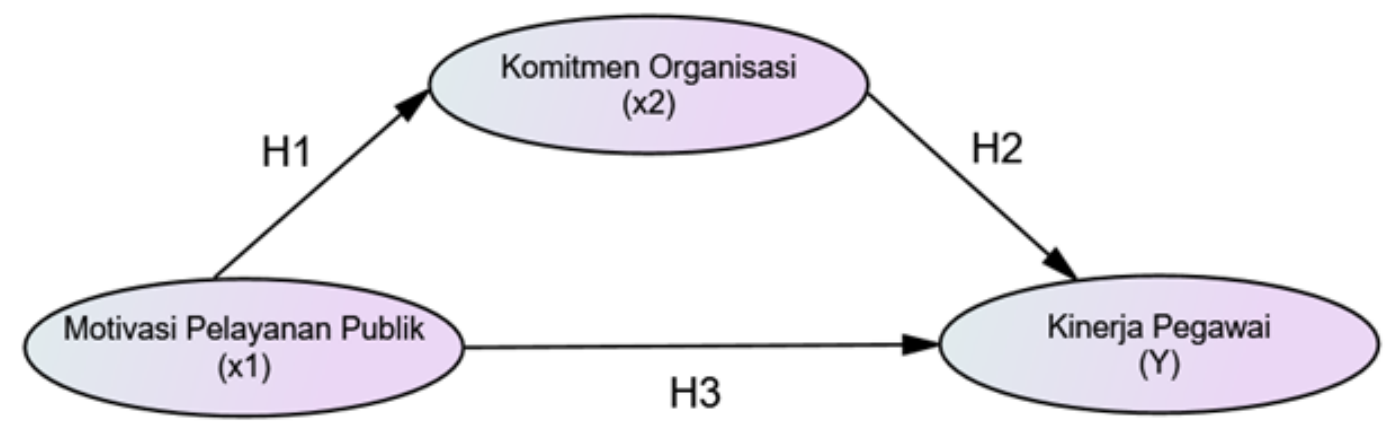

Figure 2. Conceptual Framework of PSM, Organizational Commitment, and Individual Performance

Belle( 2013) reached the conclusion that having contact with beneficiaries and selfpersuasion interventions have positive influence on performance as measured by persistence, output, productivity, and vigilance. Meanwhile, Bright (2007) in a study on 205 public employees were drawn from a public health care agency, a city government, and a county jurisdiction that were located in the states of Indiana, Kentucky, and Oregon, established that despite the fact that PSM is a critical predictor of employees' performance in public organizations, excluding Person-Organization Fit ( $\mathrm{P}-\mathrm{O})$ dimensions, resulted into of outcome where PSM had no significant direct influence the performance of public employees. In another study in Netherlands, it was established that high PSM was associated with high perception of performance (Leisink \& Steijn, 2009). In light of that, PSM is stipulated to have positive relationship with performance in public sector organizations.

H1: PSM has positive influence on individual performance

\section{PSM and Organizational Commitment}

A lot of previous research shows that PSM is a good predictor of the performance of public sector employees (Brewer, Selden, \& Facer II, 2000; Perry, 1996, 2000; Perry, Brudney, Coursey, \& Littlepage, 2008). The inference that can be drawn is that public sector employees have strong organizational commitment, which is reflected in the dedication they have for their work. In another empirical research, Camilleri \& Van Der Heijden (2007) examined the relationship between organizational commitment, PSM, and performance and found that job characteristics have a direct impact on both organizational commitment and PSM, but low indirect effect on performance. The survey was administered to 3,400 Maltese public officers. What makes our study different from Camilleri \& Van Der Heijden (2007) is the way the relationship between organizational commitment and PSM was measured in the Malta setting. Nonetheless, based on extant literature, empirical evidence shows that PSM has a positive relationship with organizational commitment (Castaing, 2006). In that backdrop, the hypothesis on the relationship between PSM and organizational commitment is stated as follows.

H2: PSM has positive influence on Organizational Commitment

\section{Organizational Commitment and Individ- ual Performance}

Previous research on organizational studies, underscores the role that commitment of employees to their daily work contributes to performance in an organization. Based on results of studies in the private sector, commitment to an organization is associated with employee performance. A metaanalysis conducted by Riketta, (2002) provides support for the premise. Employees 
Table 1. Respondents by Gender

\begin{tabular}{lccccc}
\hline & Sex & Frequency & Percent & Valid Percent & $\begin{array}{c}\text { Cumulative } \\
\text { Percent }\end{array}$ \\
\hline Valid & 1 & 44 & $62.9 \%$ & 62.9 & 62.9 \\
& 2 & 26 & $37.1 \%$ & 37.1 & 100.0 \\
& Total & 70 & $100.0 \%$ & 100.0 & \\
\hline
\end{tabular}

Source: Data Analysis

who are high performers feel happier in their workplace contribute to stronger commitment to organizations where they work. Using the results of the meta-analysis study, the following hypothesis can be made:

H3: Organizational Commitment has positive influence on individual performance

\section{METHODS}

The conduct of the study is based on a quantitative research design. To that end, the research reviewed existing theories to obtain hypotheses (Blumberg, Cooper, \& Schindler, 2011; Neuman, 2014; Saunders, Lewis, \& Thornhill, 2008). The population of this study comprised front line civil servants who are directly involved in providing services to the citizens. The study used a random sampling techniques to obtain a sample of 84 employees (consisting of civil servants and employee on part time contract arrangements). A survey was conducted with 70 respondents who are employees in various sub district offices in Magelang Municipality. The response rate was $100 \%$, this also means that we are confident that survey results reflect the views of the overall population. Using small sample in SEM analysis is considered sufficient Wolf, Harrington, Clark, \& Miller (2015).

Table 1 presents descriptive statistics of respondents. The sample of respondents comprised 44 male $(62,9 \%)$ and 26 female (37.1\%). To that end, the number of male respondents has higher than that of female respondents. With respect to age, the largest number of respondents fell in the 53-58 age bracket $(37.1 \%)$, who are retirees; second in number was the 47-52 age bracket (14 re- spondents (20\% all respondents); and only 6 respondents were in the 30-35 age bracket, and therefore had the smallest number of respondents (Table 2). It is also important to note that by and large the sample of respondents was predominantly male tenure track civil servants.

\section{Measures}

To measure each construct, respondents filled out a seven-scale semantic differential scale anchoring from 'not at all agree' to 'very strongly agree'.

\section{PSM}

The concept of PSM has its origin in a study by Perry \& Wise (1990) of public personal management in the US. Results of the study gives a typology of motives associated with public service. The motivational bases of public service in the study include, rational, norm-based, and affective motive. Perry \& Wise (1990) defines PSM as "an individual's predisposition to respond to motives grounded primarily or uniquely in public institutions". Meanwhile, Bright (2007, p. 367) defines PSM as the tendency of individuals to respond to the basic motive on public affairs, which is based on the argument that public sector employees are people who are attracted to serve in the public sector. In line with that argument, Vandenabeele, Scheepers, \& Hondeghem (2006) define PSM as "Public service motivation refers to the type of motivation to perform behavior that relates typically to the public sector; such as altruism or public interest". In a more refined definition, Vandenabeele (2007) defines PSM as "the beliefs, values, and attitudes that go beyond self-interest and organizational interest, that concern the interest of a larger political entity and that mo- 
Table 2. Respondents by Age

\begin{tabular}{cccccc}
\hline & Age & Frequency & Percent & Valid Percent & Cumulative Percent \\
\hline Valid & $30-35$ & 6 & $8.6 \%$ & 8.6 & 8.6 \\
& $36-41$ & 15 & $21.4 \%$ & 21.4 & 30.0 \\
& $42-46$ & 9 & $12.9 \%$ & 12.9 & 42.9 \\
& $47-52$ & 14 & $20.0 \%$ & 20.0 & 62.9 \\
& $53-58$ & 26 & $37.1 \%$ & 37.1 & 100.0 \\
& Total & 70 & $100.0 \%$ & 100.0 & \\
\hline
\end{tabular}

Source: Data Analysis

tivate individuals to act accordingly whenever appropriate" (p. 547).

In 1996, Perry attempted to develop PSM measurements, over the last two decades, which improved the ability of subsequent researchers to measure PSM (Ritz et al., 2016). Kim et al (2013) developed internationally comparable measure PSM, which accommodate various cultural setting. Kim (2013) measurement consists of a four dimensional (4D), 16-item measures which this study adopted. In order to measure PSM effectively, we used operational dimensions of PSM, which provided the foundation that was used to create items that were used to represent each of the four dimensions of PSM, inter alia attraction of public participation (APP), commitment to public values (CPV), and compassion (COM), and SelfSacrifice (SS).

\section{Organizational Commitment}

Organizational commitment is defined as the "strength of an individual's identification with and involvement in a particular organization" (Porter, Steers, Mowday, \& Boulian, 1974, p. 604). Thus, membership in organization is the main focus of organizational commitment (Robbins, Judge, \& Campbell, 2017). Employees who have high organizational commitment tend to have strong dedication to their work. According to Jaros (2007), Meyer and Allen's threecomponent model of organizational commitment has become the model that is often used to study employee' commitment to an organization. Dimensions of the model comprise Affective Commitment, Continuance
Commitment, and Normative Commitment (Allen \& Meyer, 1990). A revision of the model by Jaros (2007) resulted into the creation of 8 items that represent model dimensions.

\section{Individual Performance}

Robbins, Judge, \& Campbell (2017) contend that work performance depends on many factors, that transcend capabilities, motivation being one of most important of them. In the public sector, performance is gaining attention in both research and practice (van Thiel \& Leeuw, 2002). In this study we adopted Camilleri \& Van Der Heijden (2007, p. 34) by breaking down performance into formal and informal components.

Formal performance refers to the achievement of an employee in relation to the performance target that is stated in the performance contract. Meanwhile, informal performance denotes organizational politics in which employees interact in day to day administration. It thus, relates to the nonfinancial incentive and appreciation that includes promotion and career development (Vigoda, 2001). By adopting Camilleri \& Van Der Heijden (2007), this study used 2 sub dimensions that comprise 6 scales to measured measure individual commitment.

The questions were based on validated measures that are available in the extant literature. For practical purposes, specifically to facilitate data collection, questions were translated from English into Indonesian language. Nonetheless, to ensure that meaning was not lost in translation, we tested seman- 


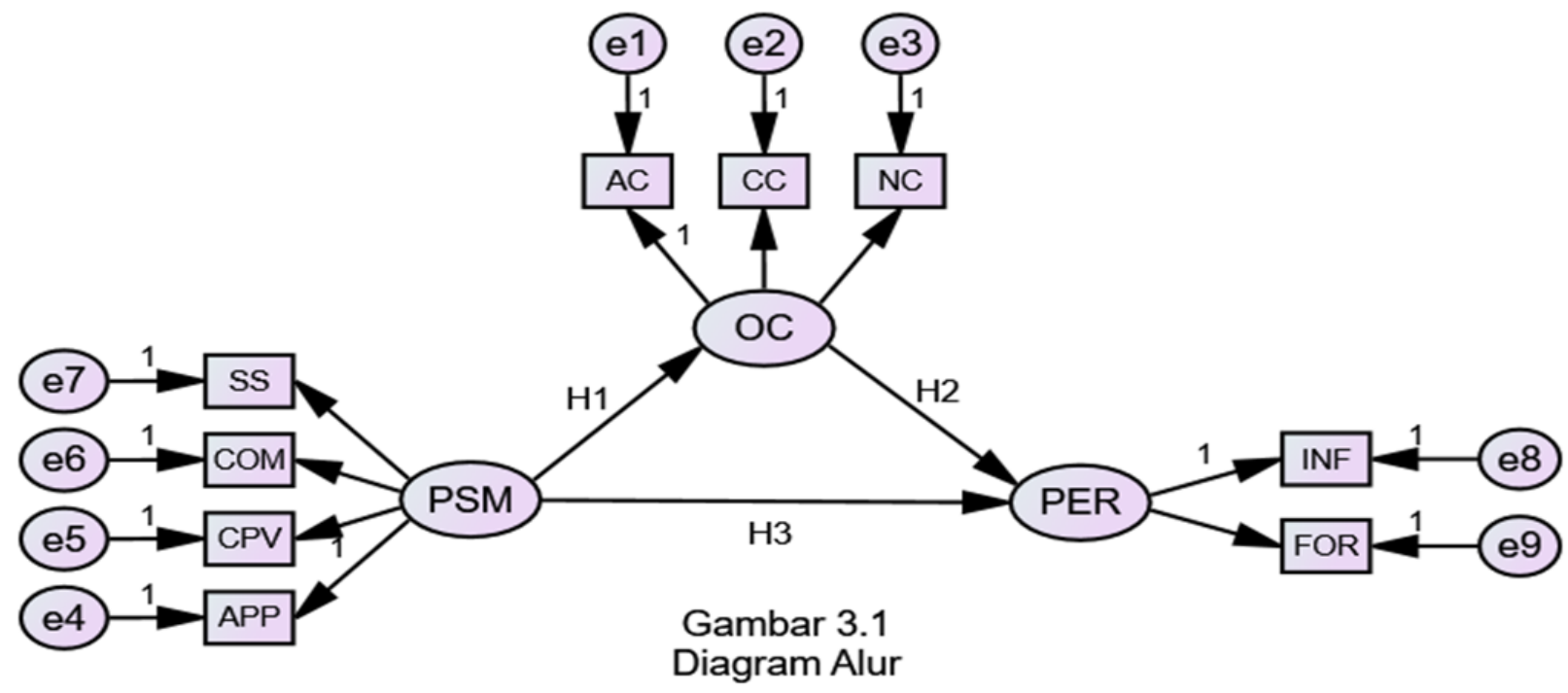

Figure 3. Model Specification

Source: Data Analysis

$\begin{array}{ll}\text { PSM } & \begin{array}{l}\text { = Relationship of exogen }\left(\mathrm{X}_{1}\right) \text { dan }\left(\mathrm{X}_{2}\right) \text { and endogen variable }(\mathrm{Y}) \\ =\end{array} \\ & \text { Consist of } 4 \text { subdimensions Atraction to public policy making (APP), } \\ \text { Comitment to public interest and civic duty (CPV), Compassion (COM) } & \text { and Self Sacrifice (SS) } \\ & =\text { Consist of } 3 \text { sub dimensions: affective, normative, and continuance. } \\ & =\text { Consist of w sub dimensions informal and formal performance } \\ \text { OC } & =\text { affective commitment } \\ \text { PER } & =\text { continuance commitment } \\ \text { AC } & =\text { normative commitment } \\ \text { CC } & =\text { self-sacrifice } \\ \text { NC } & =\text { compassion } \\ \text { SS } & =\text { commitment to public value } \\ \text { COM } & =\text { attraction of public participation } \\ \text { CPV } & =\text { informal performance } \\ \text { APP } & =\text { formal performance } \\ \text { INF } & \end{array}$

tic differential scale. Semantic differential was first used by Osgood (1964), and has become one of the recommended techniques used in SEM analysis.

Minimum Score $=1$

Maximum Score $=7$

Very disagree 122345567 Very agree

As has been indicated earlier, data analysis was based on Structural Equation Modelling (SEM). The choice of the analysis technique was based on the advantages that the method has, which include ability to estimate both latent and manifest variables, cou- pled with ability to conduct simultaneous regressions among variables (Hooper, Mullen, Hooper, Coughlan, \& Mullen, 2008; Noar, 2003). AMOS 24 application was used to estimate SEM. The software was used due to its ability to determine validity, reliability, and model fit, with validity being measured by probability value and regression weight in each construct (Ghozali, 2008).

\section{Model specification}

The SEM model requires a model specification which is drawn from and informed by theoretical assumptions. Figure 3 shows Latent and manifest variables of the 
Table 3. CFA construct test

\begin{tabular}{cccccc}
\hline $\begin{array}{c}\text { Goodness of } \\
\text { Fit Index }\end{array}$ & $\begin{array}{c}\text { Cut- off } \\
\text { Value }\end{array}$ & PSM & OC & PER & Remarks \\
\hline Chi-Square & $\begin{array}{c}\text { Expected } \\
\text { small }\end{array}$ & 45.715 & 22.179 & 8.146 & Acceptable \\
Probability & $\geq 0.05$ & 0.442 & 0.316 & 0.519 & Acceptable \\
RMSEA & $\leq 0.08$ & 0.015 & 0.051 & 0.000 & Acceptable \\
GF1 & $\geq 0.90$ & 0.898 & 0.976 & 0.962 & Acceptable \\
AGFI & $\geq 0.90$ & 0.851 & 0.919 & 0.912 & Acceptable \\
TLI & $\geq 0.90$ & 0.997 & 0.985 & 1.017 & Acceptable \\
CF1 & $\geq 0.95$ & 0.997 & 0.993 & 1.000 & Acceptable \\
\hline
\end{tabular}

Source: Data Analysis

SEM model used in this research.

\section{FINDINGS AND DISCUSSION}

We first conducted a Confirmatory Factor Analysis (CFA) to test the model fitness as presented in Table 3. CFA test results indicated that a three-construct model consisting of PSM, Organizational commitment, and individual performance was found to fulfill model fit requirements of PSM.

Subsequently, the estimation of the fully fledged model that represented the relationship between PSM, organizational commitment, and individual performance in the Magelang Municipality Sub-District Offices was made. Figure 4 shows model estimation results.

A summary of full model estimates is presented in Table 4 . The results show that model specification is accepted as a good structural model and fit to conduct in the structural equation analysis. Chi-square, Probability, RMSEA and GFI passed the cut -off values while GFI, TLI dan AGFI were within the tolerable index. Formal performance as one of the latent variable in the performance construct was eliminated because the index fell outside the acceptable limits for inclusion in the full model. To that end, despite meeting CFA requirements, formal performance was deemed not fit and suitable to be included in the full model.

\section{Reliability Test}

Reliability test was conducted to make sure that the model was reliable for use in other research setting. Estimation of the reliability was conducted using construct reliability (CR) and Average Variance Extracted (AVE). The critical value of $C R$ is 0.70 and AVE is 0.5 . Reliability test results are presented in Table 5.

Table 5 shows the construct reliability, which confirm that instruments and model used in this study are reliable. This is reflected in the CR value of 0.915 , and an AVE value of 0.554 for the PSM construct. Meanwhile, the organizational commitment construct had CR value of 0.719 and AVE of 0.604 . Lastly, the individual performance construct has a CR value of 0.583 and AVE of 0.535 . Based on previous empirical studies, the cut-off value of CR of is 0.70 and AVE of 0.5 are considered acceptable thresholds for reliability. The $\mathrm{CR}$ value of individual performance was below the recommended threshold, which was why it was excluded from the model. Thus, we are confident that the model specification we developed meets all the reliability requirements.

\section{Hypotheses Test}

Analysis test results showed that all the hypotheses on the relationships between PSM, Organizational Commitment, and Individual Performance were accepted (Table 7). Based on estimation results, the critical value of all the relationships was higher than 1.96. PSM has a strong relationship with or- 


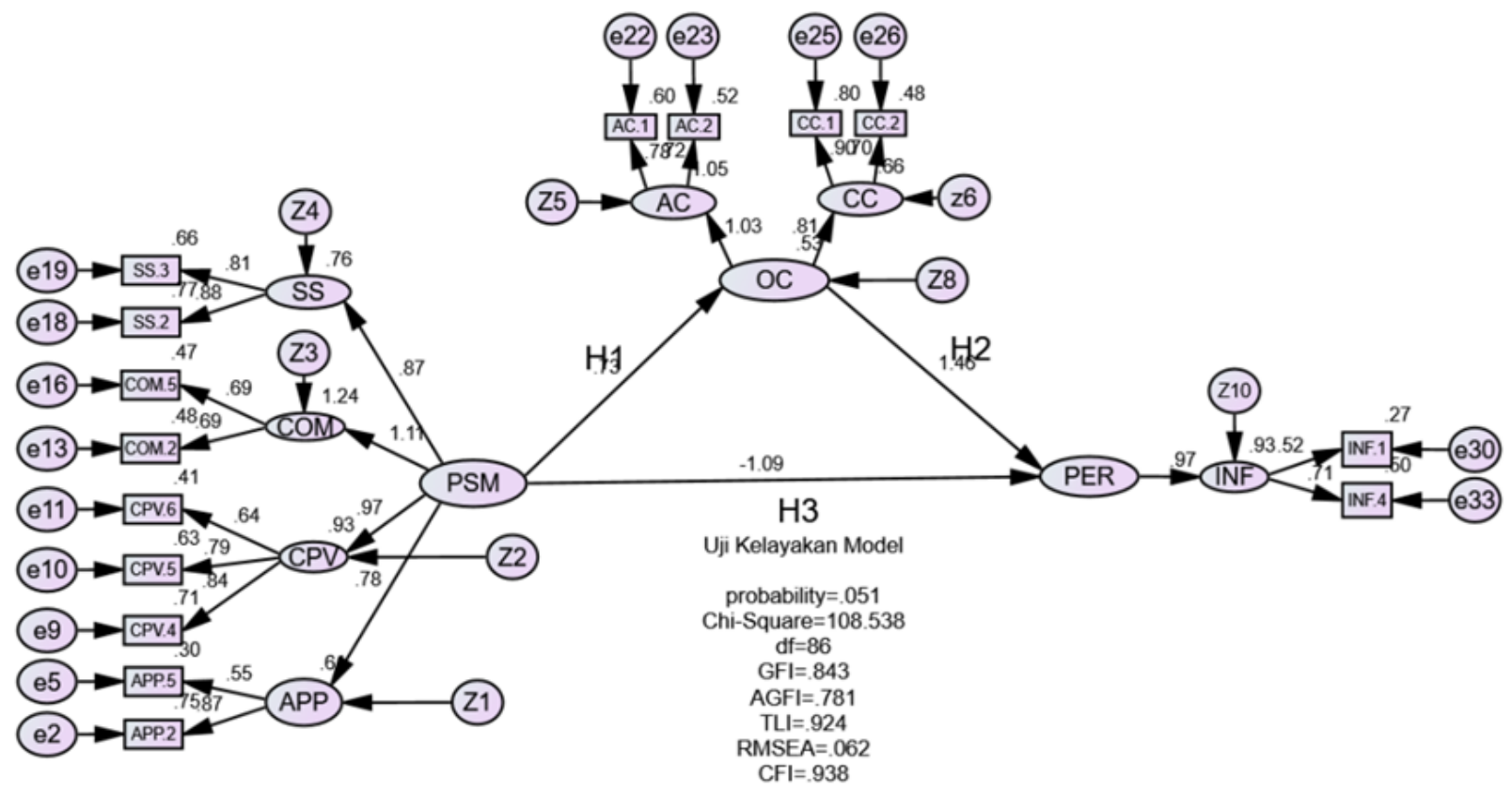

Figure 4. Model estimation of the relationship between PSM, organizational commitment, and individual performance

Source: Data Analysis

H1 : Hyphotheses 1

H2 : Hyphotheses 2

H3 : Hyphotheses 3

e1-e33 : residual/error measurement

Z1-Z10: standard estimates (regression value $=1$ )

ganizational commitment and individual performance at the $99 \%$ degree of confidence. While, organizational commitment has strong relationship with individual performance at the $95 \%$ confidence level.

The coefficient of the relationship between PSM and organizational commitment was $\mathrm{C} . \mathrm{R}=3.682$, probability $=* * *$, which means that both values met the requirements to accept the hypothesis. Meanwhile, the relationship of PSM and individual performance had C.R. of 6.215, and probability = ***, that confirmed that both values also met the requirements to accept the hypothesis. Meanwhile, the relationship between organizational commitment and individual performance registered C.R. of 3.009 , and probability (0.003), which means that both values met the requirement to accept the hypothesis at the $95 \%$ confidence level (Table $6)$.

Result of this study corroborates evidence in previous literature on PSM re- search. In regards with performance, our finding support previous research that showed a positive relationship between PSM and high employee performance in the public sector (Belle,2013; Leisink \& Steijn, 2009). Other studies also showed that supported by transformational leadership, PSM is associated with high performance in public sector organizations (Caillier, 2014), high -performance human resource practices (Mostafa, Gould-Williams, \& Bottomly, 2015), job choice (Wright, Hassan, \& Christensen, 2017) and societal impact potential (van Loon, Kjeldsen, Andersen, Vandenabeele, \& Leisink, 2018). The above research also underscore the fact that PSM and organizational performance work well under other supporting conditions, in this case leadership. To that end, explaining the relationships between PSM, organizational performance and employee commitment, requires taking into consideration other interrelated variables.

Results of this study corroborate previ- 
Table 4. Goodness of Fit Full Model

\begin{tabular}{cccl}
\hline Goodness of Fit Index & Cut- off Value & Result & Remarks \\
\hline Chi-Square & Expected to be small & 41.008 & Acceptable \\
Probability & $\geq 0.05$ & 0.51 & Acceptable \\
RMSEA & $\leq 0.08$ & 0.07 & Acceptable \\
GF1 & $\geq 0.90$ & 0.843 & Acceptable \\
AGFI & $\geq 0.90$ & 0.781 & Acceptable \\
TLI & $\geq 0.90$ & 0.924 & Acceptable \\
CF1 & $\geq 0.95$ & 0.938 & Acceptable \\
\hline
\end{tabular}

Source: Data Analysis

ous findings from both developing and developed countries that show positive association between PSM and employee performance in the public sector. In other words, the positive influence that PSM has on the performance of public-sector employee is not limited to developed countries where most of previous literature was conducted, but also in developing country context, such as Indonesia.

Moreover, results on the relationship between motivation in the public service and organizational commitment are also similar to previous study results (Camilleri \& Van Der Heijden, 2007). What makes this study different is the measurement scale used. In our study we used international PSM scale and mixed formal and informal performance scale. The finding that formal-based performance is not supported in the developing country context model may be an indication of the unreadiness of the same in contrast with the setting in developed countries.

Meanwhile, informal performance associated with office politics, performance appreciation, and career development are supported by empirical evidence. This implies that improving performance management system should take into consideration human resources management and human capital management especially in relation to PSM. The use of performance-based assessment on civil service systems is still contestable given the reality that measurement of formal performance remains relatively poorly implemented in day-to-day administra- tion. Based on study results, formal performance is not significantly associated with PSM among front-line officers.

As regards the relationship between organizational commitment and performance, results obtained corroborate previous studies that established positive association between commitment to organization and performance (Riketta, 2002; Rusu, 2013; T. A. Wright, 1997). Another study on showed a positive relationship between organizational commitment, high-intrinsic motivation and ethical leadership and performance (Potipiroon \& Ford, 2017).

\section{CONCLUSION}

Reiterating the objective of this research which was to investigate the relationship between PSM, organizational commitment, and individual performance in a developing country setting, results showed that PSM has positive relationship with individual performance and commitment to the organization. Meanwhile, results also established the existence of a positive association between organizational commitment and individual performance. Implications for public sector managers include the need for taking into consideration efforts to enhance PSM and organizational commitment as pathway for enhancing individual performance. Equally important is the need to integrate organizational commitment and PSM the implementation of programs which increases their performance. The role that hu- 
Arif Budy Pratama, Aidah Nur Hidayah — Does Public Service Motivation Matter to Employees' Performance....

Table 5. Reliability Test

\begin{tabular}{|c|c|c|c|c|c|}
\hline & Std. Loading & Std. Loading $^{2}$ & 1 - std. Loading ${ }^{2}$ & $\overline{\mathbf{C R}}$ & $\overline{\text { AVE }}$ \\
\hline \multicolumn{6}{|c|}{ PSM } \\
\hline APP.2 & 0.870 & 0.753 & 0.247 & & \\
\hline APP. 5 & 0.550 & 0.300 & 0.700 & & \\
\hline CPV.4 & 0.840 & 0.706 & 0.294 & & \\
\hline CPV.5 & 0.794 & 0.630 & 0.370 & & \\
\hline CPV.6 & 0.641 & 0.412 & 0.588 & & \\
\hline COM.2 & 0.693 & 0.480 & 0.520 & 0.915 & 0.554 \\
\hline COM.5 & 0.687 & 0.472 & 0.528 & & \\
\hline SS.2 & 0.878 & 0.771 & 0.229 & & \\
\hline SS.3 & 0.811 & 0.685 & 0.315 & & \\
\hline$\sum$ & 6.764 & 5.209 & -4.209 & & \\
\hline$\Sigma^{2}$ & 45.752 & & & & \\
\hline \multicolumn{6}{|c|}{ Organizational Commitment } \\
\hline AC.1 & 0.780 & 0.602 & 0.398 & \multirow{6}{*}{0.719} & \multirow{6}{*}{0.604} \\
\hline AC. 2 & 0.721 & 0.520 & 0.480 & & \\
\hline CC.1 & 0.896 & 0.803 & 0.197 & & \\
\hline CC. 2 & 0.695 & 0.483 & 0.517 & & \\
\hline$\sum$ & 1.501 & 1.122 & 0.878 & & \\
\hline$\Sigma^{2}$ & 2.253 & & & & \\
\hline \multicolumn{6}{|c|}{ Individual Commitment } \\
\hline INF.1 & 0.520 & 0.270 & 0.730 & \multirow{4}{*}{0.583} & \multirow{4}{*}{0.535} \\
\hline INF.4 & 0.710 & 0.504 & 0.496 & & \\
\hline$\sum$ & 1.230 & 0.775 & 1.126 & & \\
\hline$\Sigma^{2}$ & 1.513 & & & & \\
\hline
\end{tabular}

Source: Data Analysis

man resource management initiatives play in enhancing organizational commitment and PSM underscores the need for managers to consider the two variables in programs that are tailored toward improving organizational performance.

Nonetheless, results in this study are inseparable from the research design and its implementation that guided the exercise. The small size of the sample of respondents (while fulfilled the requirements for SEM analysis) may not represent the behavior of all public servants not only in Magelang municipality but also in Indonesia. The shortcoming, then, serves as the focus for future research efforts on PSM in the public sector in Indonesia. Future research efforts may replicate the study by adding more variables including organizational support, organizational climate/culture, leadership, type of organization, and others as antecedents of PSM. Increasing the sample size in each administrative tier as well as the variety of administration units and tiers covered (at the local and central government level), could shed more light on other keys factors that in addition to PSM, individual performance, organizational commitment, and organizational performance. Moreover, conducting future research along such direction may help to discover other mechanisms and dynamics through which PSM, individual performance, and organizational performance interact. 
Table 6. Regression Weights: (Group number 1 - Default model)

\begin{tabular}{llccccc}
\hline & & & Estimate & S.E. & C.R. & P \\
\hline OC & $<---$ & PSM & 0.877 & 0.238 & 3.682 & $* * *$ \\
PER & $<---$ & OC & 0.390 & 0.130 & 3.009 & .003 \\
PER & $<---$ & PSM & 1.020 & 0.164 & 6.215 & $* * *$ \\
\hline
\end{tabular}

Source: Data Analysis

\section{ACKNOWLEDGEMENT}

Authors would like to thank to civil servants working in North, Central and South Magelang municipality for their invaluable assistance during the data collection process.

\section{REFERENCES}

Allen, N. J., \& Meyer, J. P. (1990). The measurement and antecedents of affective, continuance and normative commitment to the organization. Journal of Occupational Psychology, 63(1), 1-18. http://doi.org/10.1111/ j.2044-8325.1990.tb00506.x

Bangcheng, L. (2009). Evidence of public service motivation of social workers in China. International Review of Administrative Sciences, 75(2), 349$366 . \quad$ http:// doi.org/10.1177/0020852309104180

Belle, N. (2013). Experimental Evidence on the Relationship between Public Service Motivation and Job Performance. Public Administration Review, 73(1), 143-153. http:// doi.org/10.111/j.1540-

6210.2012.02621.x.Experimental

Blumberg, B., Cooper, D. R., \& Schindler, P. S. (2011). Business research methods. London: McGraw-Hill Education.

Brewer, G. A, Selden, S. C., \& Facer II, R. L. (2000). Individual Conceptions of Public Service Motivation. Public Administration Review, 60(3), 254-264. http://doi.org/10.1111/00333352.00085

Bright, L. (2007). Does Person-Organization Fit Mediate the Relationship Between Public Service Motivation and the Job Performance of Public Employees? Review of Public Personnel
Administration, 27(4), 361-379. http:// doi.org/10.1177/0734371X07307149

Caillier, J. G. (2014). Toward a better understanding of the relationship between transformational leadership, public service motivation, mission valence, and employee performance: A preliminary study. Public Personnel Management, 43(2), 218-239. http:// doi.org/10.1177/0091026014528478

Camilleri, E., \& Van Der Heijden, B. I. J. M. (2007). Organizational Commitment, Public Service Motivation, and Performance Within the Public Sector. Public Performance \& Management Review, 31(2), 241-274. http:// doi.org/10.2753/PMR15309576310205

Castaing, S. (2006). The Effects of Psychological Contract Fulfilment and Public Service Motivation on Organizational Commitment in the French Civil Service. Public Policy and Administration Volume, 21(1), 84-98.

Daisuke, N., \& Kumorotomo, W. (1998). Pelajaran dari Reformasi Birokrasi di Jepang 1945-1952. Jurnal Kebijakan \& Administrasi Publik, 2(1), 41-57.

DPMPTSP Kota Magelang. (2016, May 30). Kota Magelang Memiliki Daya Saing Tertinggi di Jawa Tengah. Retrieved from http://bp2t.magelangkota.go.id/ index.php/15-headline/632-kotamagelang-memiliki-daya-saingtertinggi-di-jawa-tengah

Ghozali, I. (2008). Model Persamaan Struktural Konsep dan Aplikasi dengan Program Amos 16.0. Semarang: Badan Penerbit Universitas Diponegoro.

Hooper, D., Mullen, J., Hooper, D., Coughlan, J., \& Mullen, M. R. (2008). Structural Equation Modelling: Guidelines for Determining Model Fit. The Electronic Journal of Business 
Table 7. Hypotheses Testing Results

\begin{tabular}{|c|c|c|}
\hline & Hyphotheses & Result \\
\hline $\mathrm{H} 1$ & PSM relates positively with individual performance & Accepted \\
\hline $\mathrm{H} 2$ & PSM relates positively with Organizational Commitment & Accepted \\
\hline $\mathrm{H} 3$ & $\begin{array}{l}\text { Organizational Commitment relates positively with individual } \\
\text { performance }\end{array}$ & Accepted \\
\hline
\end{tabular}

Source: Data Analysis

Research Methods, 6(1), 53-60. http:// doi.org/10.1037/1082-989X.12.1.58

Jaros, S. (2007). Meyer and Allen Model of Organizational Commitment :

Measurement Issues. The Icfai Journal of Organizational Behavior, 6(4), 7-26. http:// doi.org/10.1348/096317906X118685

Kim, S., Vandenabeele, W., Wright, B. E., Andersen, L. B., Cerase, F. P., Christensen, R. K., De Vivo, P. (2013). Investigating the structure and meaning of public service motivation across populations: Developing an international instrument and addressing issues of measurement invariance. Journal of Public Administration Research and Theory, 23(1), 79-102. http://doi.org/10.1093/jopart/mus027

Leisink, P., \& Steijn, B. (2009). Public service motivation and job performance of public sector employees in the Netherlands. International Review of Administrative Sciences, 75(1), 35-52. http://

doi.org/10.1177/0020852308099505

Liando, D. M. (2012). Implementasi Kebijakan Pembentukan Daerah Otonom Baru dan Dampaknya Bagi Kualitas Pelayanan Publik. Jurnal Kebijakan \& Administrasi Publik, 16 (2), 47-62.

Liu, B.-C., \& Tang, T. L.-P. (2011). Does the Love of Money Moderate the Relationship between Public Service Motivation and Job Satisfaction? The Case of Chinese Professionals in the Public Sector. Public Administration Review, 71(5), 718-727. http:// doi.org/10.1111/j.15406210.2011.02411.x

Mostafa, A., Gould-Williams, J., \&
Bottomly, P. (2015). High-Performance Human Resource Practices and Employee Outcomes: Th e Mediating Role of Public Service Motivation. Public Adinistration Review, 75(5), 747 -757. http://doi.org/10.1111/ puar.12354.High-Performance

Neuman, W. (2014). Social research methods: Qualitative and quantitative approaches. Boston: Pearson.

Noar, S. (2003). The Role of Structural Equation Modeling in Scale Development. Structural Equation Modeling: A Multidisciplinary Journal, 10(4), 493-524. http://doi.org/10.1207/ s15328007sem 1004

Nurtanzila, L., \& Kumorotomo, W. (2015). Faktor-Faktor yang Memengaruhi Penerimaan PBB P2 di Kota Yogyakarta Pasca Pelimpahan Kewenangan Pengelolaan PBB P2 oleh Pusat Kepada Daerah. Jurnal Kebijakan \& Administrasi Publik, 19(2), 157-169.

Osgood, C. (1964). Semantic Differential Technique in the Comparative Study of Cultures1. American Anthropologist, 66(3), 171-200.

Perry, J. L. (1996). Measuring public service motivation: An assessment of construct reliability and validity. Journal of Public Administration Research and Theory, 6(1), 5-22. http:// doi.org/10.1093/ oxfordjournals.jpart.a024303

Perry, J. L. (2000). Bringing Society in: Toward a Theory of Public Service Motivation. Public Administration Research and Theory, 10(2), 471-488.

Perry, J. L., Brudney, J. L., Coursey, D., \& Littlepage, L. (2008). What drives morally committed citizens? A study of the antecedents of public service 
motivation. Public Administration Review, 68(3), 445-458. http:// doi.org/10.1111/j.1540-

6210.2008.00881.x

Perry, J. L., \& Wise, L. R. (1990). The Motivational Bases of Public Service. Public Administration Review, 50(3), 367. http://doi.org/10.2307/976618

Porter, L. W., Steers, R. M., Mowday, R. T., \& Boulian, P. V. (1974). Organizational commitment, job satisfaction, and turnover among psychiatric technicians. Journal of Applied Psychology, 59(5), 603-609. $\quad$ http://doi.org/10.1037/ h0037335

Potipiroon, W., \& Ford, M. T. (2017). Does Public Service Motivation Always Lead to Organizational Commitment? Examining the Moderating Roles of Intrinsic Motivation and Ethical Leadership. Public Personnel Management, 46(3), 211-238. http:// doi.org/10.1177/0091026017717241

Pratama, A. B. (2017a). Agencification in Asia: Lessons from Thailand, Hong Kong, and Pakistan. JKAP (Jurnal Kebijakan Dan Administrasi Publik), 21(1), 43. http://doi.org/10.22146/ jkap. 23008

Pratama, A. B. (2017b). Bureaucracy Reform Deficit in Indonesia: A Cultural Theory Perspective. Journal of Public Administration and Governance. http:// doi.org/10.5296/jpag.v7i3.11519

Riketta, M. (2002). Attitudinal Organizational Commitment and Job Performance: a Meta-Analysis. Journal of Organizatiortal Behavior, 23 (March), 257-266. http:// doi.org/10.1002/job.141

Ritz, A., Brewer, G. A., \& Neumann, O. (2016). Public Service Motivation: A Systematic Literature Review and Outlook. Public Adinistration Review, 76(3), 414-426. http://doi.org/10.1111/ puar.12505.Public

Robbins, S., Judge, T., \& Campbell, T. (2017). Organizational Behaviour. Harlow: Pearson Education inc.

Rusu, R. (2013). Affective Organizational Commitment, Organizational Normative Continuance Commitment? Commitment, or Organizational Management and
Economics, 2(2), 192-197.

Saunders, M., Lewis, P., \& Thornhill, A. (2008). Research Methods for Business Students. Research methods for business students. http:// doi.org/10.1007/s13398-014-0173-7.2

Van der Wal, Z. (2015). "All quiet on the non-Western front?" A review of public service motivation scholarship in nonWestern contexts. Asia Pacific Journal of Public Administration, 37(2), 69-86. http://

doi.org/10.1080/23276665.2015.10412 23

Van Loon, N., Kjeldsen, A. M., Andersen, L. B., Vandenabeele, W., \& Leisink, P. (2018). Only When the Societal Impact Potential Is High? A Panel Study of the Relationship Between Public Service Motivation and Perceived Performance. Review of Public Personnel Administration, 38(2), 139-166. http:// doi.org/10.1177/0734371X16639111

Van Thiel, S., \& Leeuw, F. L. (2002). The Performance Paradox in the Public Sector. Public Performance \& Management Review, 25(3), 267-281. http://doi.org/10.2307/3381236

Vandenabeele, W. (2007). Toward a Public Administration Th eory of Public Service Motivation: An Institutional Approach. Public Management Review, 9(4), 45-56.

Vandenabeele, W. (2007). Toward a public administration theory of public service motivation: An institutional approach. Public Management Review, 9(4), 545556. doi.org/10.1080/14719030701726697

Vandenabeele, W., Scheepers, S., \& Hondeghem, A. (2006). Public service motivation in an international comparative perspective: The UK and Germany. Public Policy and ..., 21(1), 13-31.

Vigoda, E. (2001). Performance in the Third Sector: a Micro-Level Framework and Some Lessons From Israel. International Journal of Public Administration, 24(11), 1267-1288. http://doi.org/10.1081/PAD-100105238

Wolf, E. J., Harrington, K. M., Clark, S. L., \& Miller, M. W. (2015). Sample Size Requirements for Structural Equation 
Arif Budy Pratama, Aidah Nur Hidayah — Does Public Service Motivation Matter to Employees' Performance....

Models: An Evaluation of Power, Bias, and Solution Propriety. National Institutes of Health, 76(6), 913-934. http://

doi.org/10.1177/0013164413495237.Sa mple

Wright, B. E., Hassan, S., \& Christensen, R.

K. (2017). Job Choice and Performance: Revisiting Core Assumptions about Public Service Motivation. International Public Management Journal, 20(1), 108-131. http://

doi.org/10.1080/10967494.2015.10884 93
Wright, T. A. (1997). Job performance and organizational commitment. Perceptual and Motor Skills, 85, 447 -450. http://doi.org/10.2466/ pms.1997.85.2.447 